\begin{tabular}{|c|c|}
\hline Title & $\begin{array}{l}\text { Geographical variations in infection by larval A nisakis simplex and Contracaecum osculatum (Nematoda, A nisakidae) } \\
\text { in wall leye pollock Theragra chal cogramma stocks off Hokkaido, Japan }\end{array}$ \\
\hline Author(s) & Konishi, Kenji; Sakurai, Y asunori \\
\hline Citation & $\begin{array}{l}\text { Fisheries Science, 68(3), 534.542 } \\
\text { https://doi.org/10.1046j.1444.2906.2002.00459.x }\end{array}$ \\
\hline Issue Date & $2002-06$ \\
\hline DOC URL & http:/hdl. handle.net/2115/35583 \\
\hline Rights & ○ 2002 公益社団法人日本水産学会; @ 2002 T he Japanese Society of Fisheries Science \\
\hline Type & article \\
\hline File Information & 2002-68_p534-542.pdf \\
\hline
\end{tabular}

Instructions for use 


\title{
Geographical variations in infection by larval Anisakis simplex and Contracaecum osculatum (Nematoda, Anisakidae) in walleye pollock Theragra chalcogramma stocks off Hokkaido, Japan
}

\author{
KENJI KONISHI ${ }^{a *}$ AND YASUNORI SAKURAI \\ Graduate School of Fisheries Science, Hokkaido University, Hakodate, Hokkaido 041-8611, Japan
}

\begin{abstract}
Stocks of walleye pollock Theragra chalcogramma collected from: (i) the Sea of Japan (off Rebun Island and Kumaishi); (ii) the Pacific coast (off Shikabe and eastern Hokkaido); and (iii) Nemuro Strait off Hokkaido, northern Japan, were examined for anisakid nematodes during December 1999 to February 2000, and the prevalence and abundance of Anisakis simplex and Contracaecum osculatum larvae were compared among the various sampling sites for fish of the same size and age. Anisakis simplex was generally more abundant than $C$. osculatum. Infection by $A$. simplex varied between the aforementioned stocks of walleye pollock as well as within stocks, whereby fish from off Rebun Island and Nemuro Strait were infected the most, followed by those from off the Pacific coast and Kumaishi. Infection by $C$. osculatum differed between the host stocks, and C. osculatum was the most abundant among the fish from Nemuro Strait. The infection variations seemed to be due to differences in host growth rate, host feeding habit, and the distribution of marine mammal final hosts. The results indicate that these two larval nematodes are useful biological indicators for the population study of walleye pollock in Japanese waters.
\end{abstract}

KEY WORDS: Anisakidae, Anisakis simplex, Contracaecum osculatum, geographic variation, Nematoda, Theragra chalcogramma, walleye pollock.

\section{INTRODUCTION}

Walleye pollock Theragra chalcogramma is one of the most abundant and commercially exploited fish species around northern Japan, where it occurs at bottom or midwater depths above the continental shelf and slope. ${ }^{1,2}$ Because walleye pollock is distributed broadly in the North Pacific, understanding the distinctiveness between populations is important for the successful management of walleye pollock fisheries. ${ }^{3}$ Walleye pollock in Japanese waters is generally divided into several stocks (Sea of Japan, Pacific coast, Sea of Okhotsk and Nemuro Strait), based on tagging surveys,

*Corresponding author: Tel: 81-3-3536-6521. Fax: 81-3-35366522. Email: konishi@i-cetacean-r.or.jp

aPresent address: The Institute of Cetacean Research, 4-5 Toyomi-cho, Chuo-ku, Tokyo 104-0055, Japan.

Received 13 April 2001. Accepted 7 December 2001. morphometrics and meristics. ${ }^{1,4-7}$ However, the distribution of walleye pollock changes annually in relation to environmental factors; ${ }^{2}$ therefore, more detailed information on the populations that form these stocks and on their migration routes has become increasingly important.

Many different methods should be used to increase the efficiency and accuracy of fish population studies, and parasitological analyses of marine fishes can provide useful information on the ecology of a host species. ${ }^{8-12}$ The advantage of such a method is that it is inexpensive and does not require the recapturing of the same individuals, unlike conventional artificial tagging. ${ }^{13}$ The basic principle of the method is based on the fact that the infection rate of parasites varies among their host populations depending on feeding habits, migration routes or growth rates.

Several attempts have been made to define stocks and determine the migration routes of walleye pollock in Canadian and Russian waters 
using parasites. ${ }^{3,14,15}$ Larval anisakid nematodes, such as the whaleworm Anisakis simplex (Rudolphi, 1809) and Contracaecum osculatum (Rudolphi, 1802), are transported by crustaceans to fishes and squids as paratenic hosts and finally ingested by marine mammal definitive hosts. ${ }^{16-19}$ Their third-stage larvae commonly occur in the viscera of walleye pollock. ${ }^{20-24}$ Because the feeding habits of walleye pollock vary geographically in Japanese waters, ${ }^{25-27}$ differences in the abundance of anisakid larvae in walleye pollock can be used to define the stocks or their feeding locations. Previous ecologic surveys of anisakid nematodes from walleye pollock in Japanese waters have shown a broad variation of infection among sampling sites. ${ }^{20,21,28}$ However, the walleye pollock examined in these studies were collected throughout the year including summer, when various walleye pollock stocks sometimes mix at feeding grounds. ${ }^{7}$ Thus, these data can not be used to compare stocks. In addition, ecologic surveys of anisakid larvae in walleye pollock have not been carried out for more than two decades.

The aim of the present study was to elucidate the geographic variation in the prevalence and abundance of $A$. simplex and $C$. osculatum larvae in different walleye pollock stocks off Hokkaido, Japan in winter when the stocks separate into their respective spawning areas.

\section{MATERIALS AND METHODS}

\section{Sampling}

Walleye pollock were collected at five sites (Rebun Island, Kumaishi, Shikabe, Nemuro Strait, and eastern Hokkaido) off Hokkaido, Japan from December 1999 to February 2000 (Fig. 1). The collection comprised walleye pollock from three stocks: (i) Sea of Japan (Rebun Island and Kumaishi); (ii) Pacific coast (Shikabe and eastern Hokkaido); and (iii) Nemuro Strait. Fish from off Rebun Island, Kumaishi, Shikabe and in Nemuro Strait were collected from commercial catches, and fish from off eastern Hokkaido were collected by the Hokkaido National Fisheries Research Institute (HNFRI) using bottom or midwater trawls (Table 1).

\section{Treatment of samples}

The fish samples were either frozen immediately after collection, brought to the laboratory and then thawed at room temperature for later examination, or dissected within $24 \mathrm{~h}$ after collection. The fish were sexed and measured to the nearest millimeter from the tip of the snout to the fork of the caudal fin, and otoliths from each specimen were removed for age determination. The otoliths were examined by the HNFRI, the Hokkaido Fisheries Experimental Station (FHES), or by KK to assess each specimen's age using the break and burn method. ${ }^{29}$ The fish were then divided into both 1 year age classes and 25-mm length classes. Fish smaller than $300 \mathrm{~mm}$ were not included in the analyses. Anisakis simplex (L3), which had been

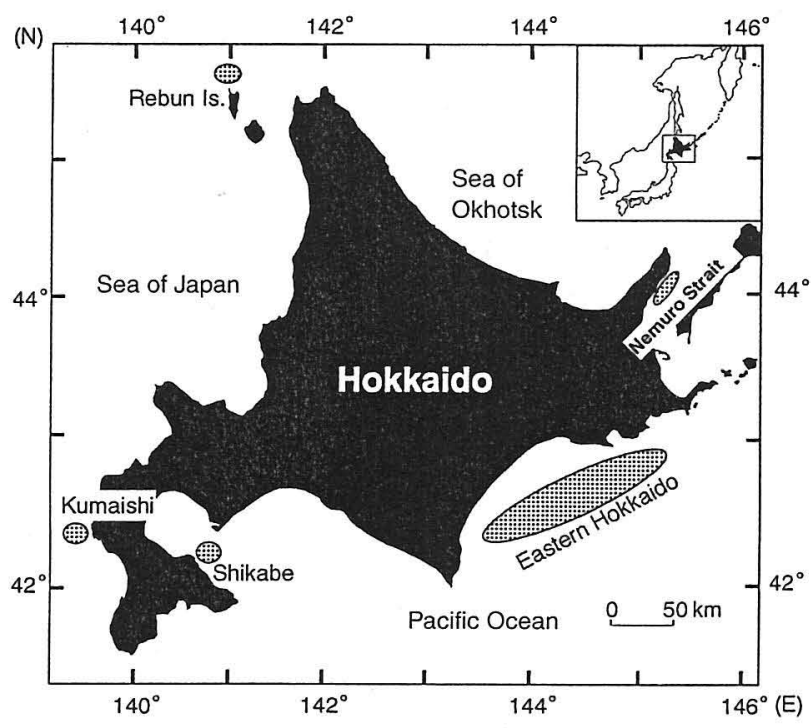

Fig. 1 Map of Hokkaido, northern Japan showing five sites where walleye pollock Theragra chalcogramma were collected.

Table 1 General information on walleye pollock (Theragra chalcogramma) collected off the coast of Hokkaido, Japan

\begin{tabular}{lcccc}
\hline Sampling areas & Sampling dates & $N$ & Fishing gear & Mean length with range (mm) \\
\hline Rebun Is. & Jan/2000 & 131 & Trawl net & $446.1(371-582)$ \\
Kumaishi & Dec/1999 & 100 & Longline & $396.5(325-491)$ \\
Shikabe & Jan/2000 & 100 & Gill net & $429.6(372-495)$ \\
East. Hokkaido & Jan/2000 & 423 & Trawl net & $371.6(300-538)$ \\
Nemuro Strait & Feb/2000 & 197 & Gill net & $468.0(360-622)$ \\
\hline
\end{tabular}


described as Anisakis type I larva, ${ }^{30,31}$ and Contracaecum osculatum (L3), which had been described as Contracaecum type $\mathrm{A}^{31}$ or type $\mathrm{B},{ }^{30}$ were removed from the fish mesenteries, pyloric caeca and livers, and were counted.

\section{Numerical analyses and statistics}

Nematode infections were compared among the same length classes and age classes from different stocks. 'Prevalence' was defined as the percentage of infected hosts, and 'abundance' was defined as the number of parasites per host. ${ }^{32}$ Because growth rates differ among walleye pollock stocks ${ }^{4,33}$ (Fig. 2 ), prevalence and abundance were analysed for both host length classes and age classes. Walleye pollock from each sampling site had different length distributions, probably due to the differences in fishing gears; therefore, statistical tests were conducted on data from three length classes (400-424 mm, 425-449 mm, 450-474 mm) and from fish aged 4-7 years.

As the frequency distributions of abundance data were positively skewed, these data were $\log _{10}(x+1)$ transformed to bring the data closer to normal distributions for parametric analyses. ${ }^{34}$ Because of the fact that there are differences in the infection of anisakid larvae between male and female fish, ${ }^{22,35}$ the abundance of the two larval nematodes in males and female hosts were compared in the $400-424 \mathrm{~mm}$ length class and in the age 4 class using Student's $t$-test. To compare the abundances among sampling stations for the same length classes and age classes, a one-way ANOva

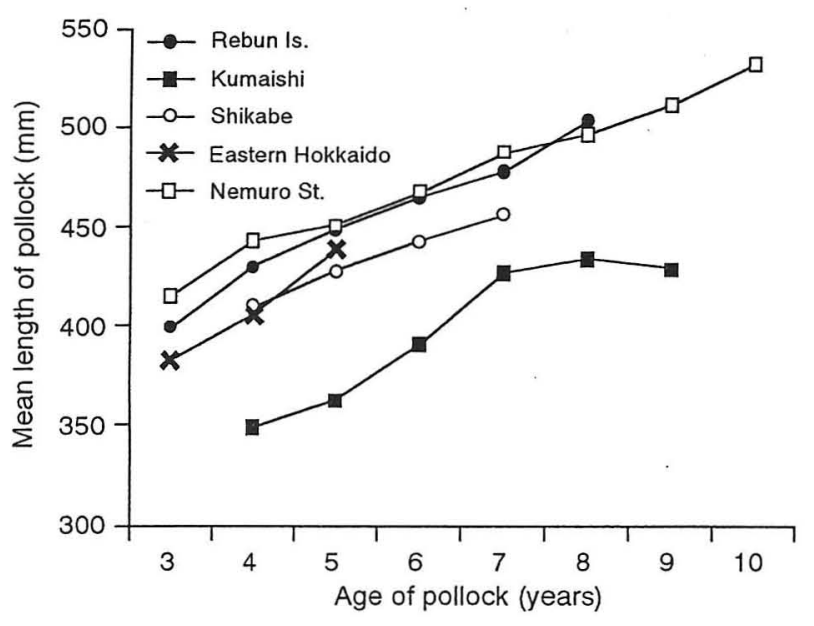

Fig. 2 Age-length relationships for walleye pollock (Theragra chalcogramma) collected at five sites off Hokkaido, northern Japan. and a post-hoc Tukey's test were used. The significance of the relationships between nematode abundance and host length or age classes were tested using Kendall's rank correlation test. For the correlation analyses between larval abundances and host age, walleye pollock from off Shikabe and eastern Hokkaido were not included because of their small sample sizes.

\section{RESULTS}

\section{Comparison of larval nematode abundance between host sexes}

No significant difference in the nematode abundance was found between the host sexes in the 400-424-mm length class for both Anisakis simplex $(t=1.15$, d.f. $=105, P=0.25)$ and Contracaecum osculatum ( $t=1.40$, d.f. $=105, P=0.16)$. In contrast, nematode abundances differed significantly between age 4 male and female walleye pollock for A. simplex $(t=2.05$, d.f. $=204, P<0.05)$, but not for C. osculatum ( $t=-0.65$, d.f. $=204, P=0.16)$. Therefore, data from male and female hosts were separated to compare $A$. simplex abundance among sampling sites according to host age. Male and female data were combined for all other analyses.

\section{Anisakis simplex larvae in walleye pollock}

The prevalence of $A$. simplex was high (>80\%) in all host length classes at all sampling sites, except off Kumaishi in the 400-424-mm length class (Table 2). The abundance of $A$. simplex differed significantly among sampling sites $(F=7.79$, d.f. $=4, P=$ $0.0001)$, and the fish from Kumaishi were significantly less abundant than those from the other four sites in the 400-424-mm length class (Table 2). However, no significant difference in abundance was found among sampling sites in the 425-449mm length class $(F=1.791$, d.f. $=4, P=0.1324)$. The abundance of $A$. simplex in the $450-4740-\mathrm{mm}$ length class differed significantly among sampling sites ( $F=5.54$, d.f. $=3, P=0.01$ ), and the fish from off eastern Hokkaido were significantly less abundant than those from off Rebun Island, Shikabe and Nemuro Strait (Table 2). Abundance in fish from off Kumaishi was lowest for all host age classes (Fig. 3).

The mean abundance of $A$. simplex larvae was correlated significantly with host size from off Rebun Island, Kumaishi and Nemuro Strait $(\tau=$ $0.90, P=0.001 ; \tau=0.71, P=0.05 ; \tau=0.71, P=0.05$, respectively). Those were also correlated significantly with the host age only for female walleye pollock from off Rebun Island, Kumaishi and 

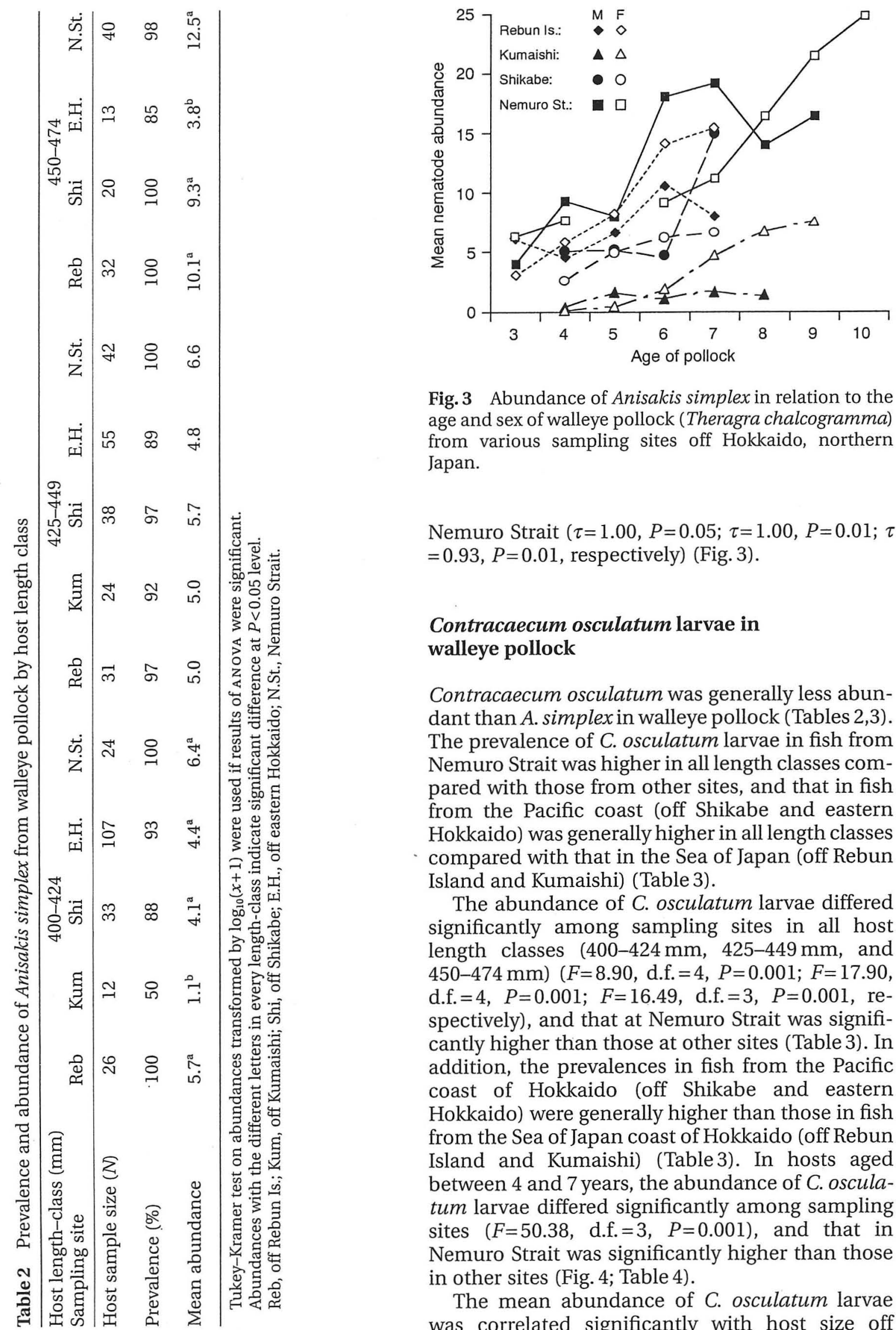

Fig. 3 Abundance of Anisakis simplex in relation to the age and sex of walleye pollock (Theragra chalcogramma) from various sampling sites off Hokkaido, northern Japan.

Nemuro Strait ( $\tau=1.00, P=0.05 ; \tau=1.00, P=0.01 ; \tau$ $=0.93, P=0.01$, respectively) (Fig. 3 ).

\section{Contracaecum osculatum larvae in walleye pollock}

Contracaecum osculatum was generally less abundant than A. simplex in walleye pollock (Tables 2,3). The prevalence of C. osculatum larvae in fish from Nemuro Strait was higher in all length classes compared with those from other sites, and that in fish from the Pacific coast (off Shikabe and eastern Hokkaido) was generally higher in all length classes compared with that in the Sea of Japan (off Rebun Island and Kumaishi) (Table 3).

The abundance of $C$. osculatum larvae differed significantly among sampling sites in all host length classes $(400-424 \mathrm{~mm}, 425-449 \mathrm{~mm}$, and $450-474 \mathrm{~mm})(F=8.90$, d.f. $=4, P=0.001 ; F=17.90$, d.f. $=4, P=0.001 ; F=16.49$, d.f. $=3, P=0.001$, respectively), and that at Nemuro Strait was significantly higher than those at other sites (Table 3). In addition, the prevalences in fish from the Pacific coast of Hokkaido (off Shikabe and eastern Hokkaido) were generally higher than those in fish from the Sea of Japan coast of Hokkaido (off Rebun Island and Kumaishi) (Table 3). In hosts aged between 4 and 7 years, the abundance of C. osculatum larvae differed significantly among sampling sites $(F=50.38$, d.f. $=3, P=0.001)$, and that in Nemuro Strait was significantly higher than those in other sites (Fig. 4; Table 4).

The mean abundance of $C$. osculatum larvae was correlated significantly with host size off 

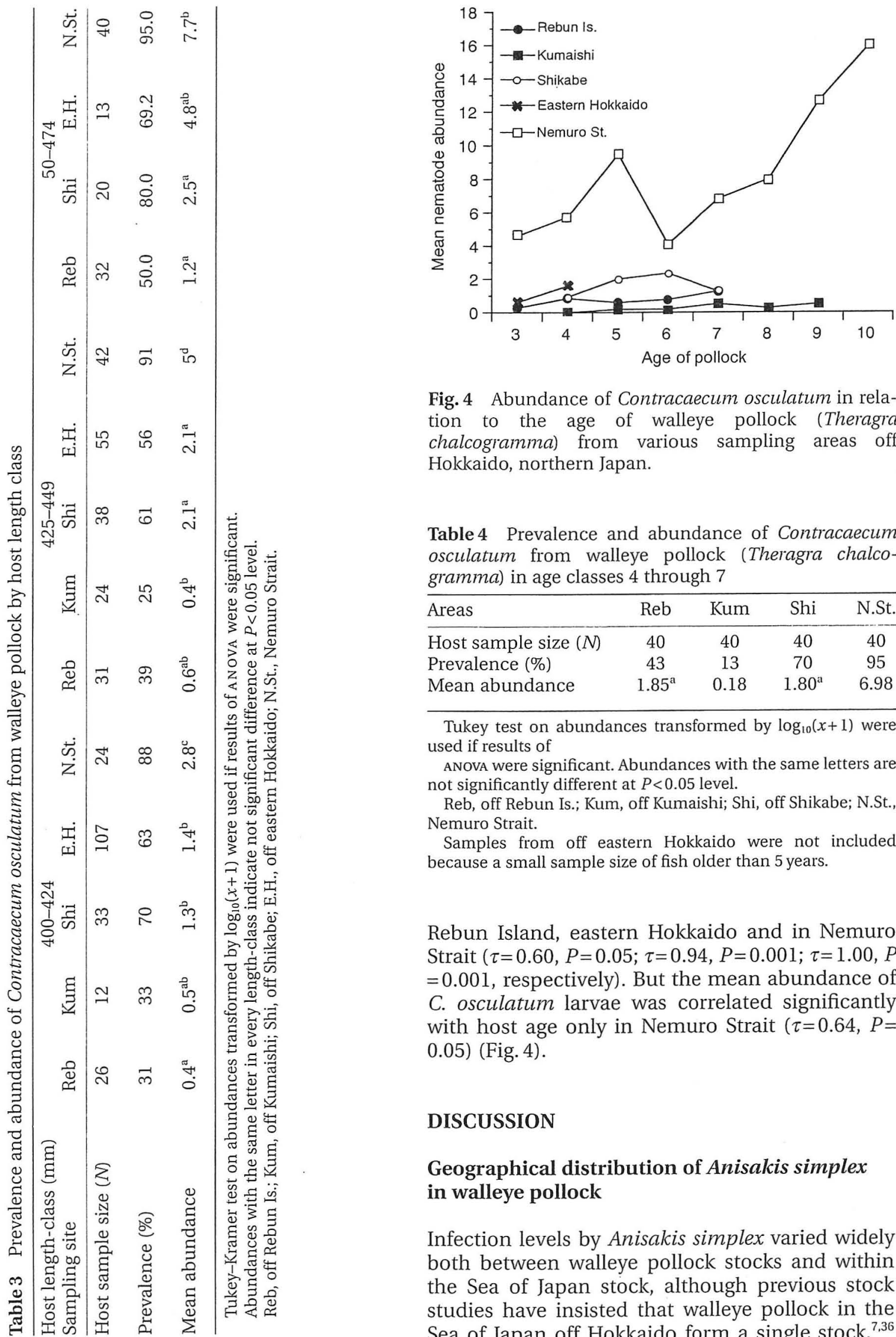

Fig. 4 Abundance of Contracaecum osculatum in relation to the age of walleye pollock (Theragra chalcogramma) from various sampling areas off Hokkaido, northern Japan.

Table 4 Prevalence and abundance of Contracaecum osculatum from walleye pollock (Theragra chalcogramma) in age classes 4 through 7

\begin{tabular}{lcccc}
\hline Areas & Reb & Kum & Shi & N.St. \\
\hline Host sample size $(N)$ & 40 & 40 & 40 & 40 \\
Prevalence (\%) & 43 & 13 & 70 & 95 \\
Mean abundance & $1.85^{\mathrm{a}}$ & 0.18 & $1.80^{\mathrm{a}}$ & 6.98
\end{tabular}

Tukey test on abundances transformed by $\log _{10}(x+1)$ were used if results of

ANOva were significant. Abundances with the same letters are not significantly different at $P<0.05$ level.

Reb, off Rebun Is.; Kum, off Kumaishi; Shi, off Shikabe; N.St., Nemuro Strait.

Samples from off eastern Hokkaido were not included because a small sample size of fish older than 5 years.

Rebun Island, eastern Hokkaido and in Nemuro Strait ( $\tau=0.60, P=0.05 ; \tau=0.94, P=0.001 ; \tau=1.00, P$ $=0.001$, respectively). But the mean abundance of C. osculatum larvae was correlated significantly with host age only in Nemuro Strait $(\tau=0.64, P=$ 0.05 ) (Fig. 4).

\section{DISCUSSION}

\section{Geographical distribution of Anisakis simplex in walleye pollock}

Infection levels by Anisakis simplex varied widely both between walleye pollock stocks and within the Sea of Japan stock, although previous stock studies have insisted that walleye pollock in the Sea of Japan off Hokkaido form a single stock. ${ }^{7,36}$ 
Previous studies on $A$. simplex in walleye pollock ${ }^{20,21}$ have shown similar results concerning such interstock variations. Walleye pollock from off Rebun Island and Nemuro Strait were generally higher in both the abundance and prevalence of A. simplex compared with those from the other sites, and the fish from the Pacific coast (off Shikabe and eastern Hokkaido) were generally higher than those from off Kumaishi. Furthermore, the abundance of $A$. simplex larvae in larger walleye pollock differed significantly between the two sites off the Pacific coast of Hokkaido (Shikabe and eastern Hokkaido).

Variation in the nematode abundance in walleye pollock among sampling sites was similar to that in the prey composition among and within walleye pollock stocks. Infection by $A$. simplex occurs when walleye pollock feeds on infected prey. Euphausiids are a major crustacean host of $A$. simplex, ${ }^{19,37-42}$ thus the intensity of predation on euphausiids may be an important factor that determines infection levels. Walleye pollock that spawn in Nemuro Strait migrate to the Sea of Okhotsk to feed, ${ }^{43,44}$ and euphausiids are the dominant prey of walleye pollock in the Sea of Okhotsk off Hokkaido. ${ }^{25}$ Walleye pollock off the Pacific coast of Hokkaido feed on many prey items according to their development stage; that is, small walleye pollock in this area feed mainly on euphausiids, copepods and amphipods, whereas larger walleye pollock are more piscivorous and feed on larger prey (e.g. micronektonic fishes and small walleye pollock), in addition to the aforementioned crustaceans. ${ }^{25,26,45}$ In the Sea of Japan off northern Hokkaido, walleye pollock feed mainly on euphausiids, ${ }^{25}$ whereas in the Sea of Japan off southern Hokkaido coast, they feed mainly on amphipods, chaetognaths and euphausiids. ${ }^{27}$ Thus, a high consumption of euphausiids by walleye pollock is an important factor causing the high infection rates of $A$. simplex.

Geographical variation in infection by $A$. simplex within the Sea of Japan off Hokkaido (off Rebun and Kumaishi) seems to be related to the difference in the growth rate of walleye pollock. Kooka has reported that walleye pollock in the Sea of Japan off southern Hokkaido have a low growth rate; ${ }^{33}$ hence, the low infection rate in the host from Kumaishi may be associated with the lower feeding rates in this area.

Infection in larger walleye pollock (450$474 \mathrm{~mm}$ ) from eastern Hokkaido was also low, and this is presumably caused not by a low feeding rate, but by small-scale variations in the migration and spawning area within the Pacific stock. The Pacific stock has a large spawning ground near Shikabe, and most of the mature walleye pollock from the
Pacific coast of Hokkaido migrate to that spawning ground in winter. ${ }^{46}$ However, some walleye pollock spawn along the coast of eastern Hokkaido. ${ }^{46}$ Most walleye pollock in the $450-474 \mathrm{~mm}$ length class have reached the size of sexual maturity; ${ }^{1}$ hence, the difference in nematode abundance in larger walleye pollock between Shikabe and eastern Hokkaido was probably more distinct in larger fish than in smaller fish, suggesting that walleye pollock from Shikabe have different feeding grounds as well as spawning areas from fish from eastern Hokkaido, which could be the cause of the different infection levels of walleye pollock between these localities.

The distribution of the definitive hosts of $A$. simplex may also influence the infection in walleye pollock. Anisakis simplex matures and releases eggs into seawater when it occurs in its definitive host. ${ }^{17,47}$ Thus, the distribution of its definitive hosts will largely determine the area where $A$. simplex larvae occur. The major definitive hosts of A. simplex are cetaceans, ${ }^{48}$ and minke whale $\mathrm{Bal}$ aenoptera acutorostrata is one of the major definitive host species in the north-west North Pacific. ${ }^{49}$ Northern North Pacific minke whales occur mainly off the coast of northern Japan in summer, ${ }^{50}$ including the areas studied in the present report. However, A. simplex appears to exhibit little host specificity, ${ }^{48,51}$ so how other cetacean species affect the infection by $A$. simplex in walleye pollock remains unknown.

The abundance of $A$. simplex in walleye pollock increased significantly with both length and age of female hosts. A similar increase in the abundance of A. simplex in relation to host size has been reported in rockfish Sebastes capensis ${ }^{52}$ and in Atlantic cod Gadus morhua. ${ }^{35}$ As A. simplex larvae seem to live at least 2 or 3 years in host fish, ${ }^{53,54}$ older fish are usually more heavily infected by larvae than younger ones. Higher consumption rates by older (larger) fish also increase the chance for infection by $A$. simplex. In contrast, the abundance of larvae was not correlated with the age of male walleye pollock. Hemmingsen et al. have suggested that differences in infection of anisakid larvae between male and female Atlantic cod were caused by differences in their feeding habits. ${ }^{35}$ However, such differences have not yet been reported in walleye pollock.

The results of the present study show that $A$. simplex can be used as a biological indicator of walleye pollock. Abundances of A. simplex can be used to divide some previously defined walleye pollock stocks, and used to divide the Sea of Japan and Pacific stocks into at least two respective substocks. These substocks probably have different feeding areas and migration routes. 
Geographical distribution of Contracaecum osculatum in walleye pollock

Infection by C. osculatum differed among walleye pollock stocks, and the highest infection by C. osculatum larvae was seen in the hosts from Nemuro Strait for all length and age classes.

Contracaecum osculatum matures in the stomachs of pinniped definitive hosts and releases eggs into seawater with the pinniped feces. ${ }^{55}$ Hatched larvae are then ingested by crustaceans and passed on to fishes, and finally transmitted to their definitive hosts. ${ }^{18}$ Larval C. osculatum occur in euphausiids $s^{56}$ and copepods. ${ }^{18}$ Although euphausiids and copepods are both preyed upon by walleye pollock from all the sites studied, ${ }^{25-27,45}$ the present study's results showed heavy infection occurred only in walleye pollock from Nemuro Strait. Boily and Marcogliese have stated that the distribution of definitive hosts could strongly reflect the occurrence of C. osculatum. ${ }^{57}$ In Japanese waters, the definitive hosts of C. osculatum include Steller sea lions Eumetopias jubatus, northern fur seals Callorhinus ursinus, spotted seals Phoca largha, and ribbon seals $P$. fasciata. $^{58}$ All are abundant in Japanese waters, but in species other than ribbon seals, few larvae mature to adulthood ${ }^{59}$ (Takahashi C., pers. comm., 1999). Ribbon seal occurs only in the Sea of Okhotsk ${ }^{60}$ where it is commonly infected by C. osculatum. ${ }^{61}$ Thus, the distribution of ribbon seal presumably affects the infection of C. osculatum in walleye pollock. As noted earlier, the Nemuro Strait walleye pollock stock feed in the Sea of Okhotsk, therefore the infection of the fish in this stock probably occurred in the Sea of Okhotsk. The abundance of $C$. osculatum was correlated significantly with walleye pollock length, but not with the host age for all stocks except the Nemuro Strait stock. This suggests that the abundance of $C$. osculatum in walleye pollock was affected only by the amount of prey consumed by fish because parasites with a shorter life span in the host will not reflect long-time fluctuations of abundance. Walleye pollock in Nemuro Strait feed mainly on euphausiids irrespective of their length; therefore, the higher consumption rates by larger fish increase the chance for infection by C. osculatum in Nemuro Strait.

the study's results indicate that infection by $C$. osculatum can be used to divide previously'defined walleye pollock stocks, although within-stock variation was not found. The Nemuro Strait stock was characterized distinctly by the high abundance of C. osculatum. Thus, the present study showed different infection patterns between A. simplex and C. osculatum from some walleye pollock stocks around Hokkaido, indicating that the two larval nematodes are both useful biological indicators for population studies of walleye pollock in Japanese waters.

\section{ACKNOWLEDGMENTS}

We thank S. Honda and A. Nishimura, Hokkaido National Fishery Research Institute, and O. Shida, T. Mutou, Y. Mihara and A. Wada, Hokkaido Fisheries Experimental Station, for providing the walleye pollock samples and age data. We also thank J. R. Bower, Hokkaido University, and K. Nagasawa, National Research Institute of Far Seas Fisheries, for their helpful comments on the manuscript, and T. Hirota, Tokyo University of Agriculture \& Technology, for providing an excellent computer program for non-parametric statistics.

\section{REFERENCES}

1. Yoshida H. Walleye pollock Theragra chalcogramma (Pallas). In: Nagasawa K, Torisawa M (eds). Fishes and Marine Invertebrates of Hokkaido: Biology and Fisheries. Kita-nihon Kaiyo Center Co. Ltd, Sapporo. 1991; 120-125.

2. Maeda T, Takagi S, Kamei Y, Kajiwara Y, Meguro T, Nakatani T. History and methodology of walleye pollock studies. Sci. Rep. Hokkaido Fish. Exp. Stn 1993; 42: 1-14.

3. Arthur JR. A preliminary analysis of the discreteness of stocks of walleye pollock (Theragra chalcogramma) from the northeastern Pacific Ocean off Canada based on their parasites. Can. Tech. Rep. Fish. Aquat. Sci. 1983; 1184: 15.

4. Ishida A. On the age determination and morphometrical differences of the otolith of Alaska pollock in the Hokkaido coast. Bull. Hokkaido Reg. Fish. Res. Lab. 1954; 11: 36-49.

5. Hashimoto R, Koyachi S. Geographical variation of relative growth of walleye pollack Theragra chalogramma (Pallas). Bull. Tohoku Reg. Fish. Res. Lab. 1977; 38: 41-74.

6. Koyachi S, Hashimoto R. Preliminary survey of variations of meristic characters of walleye pollock Theragra chalcogramma. Bull. Tohoku Reg. Fish. Res. Lab. 1977; 38: 17-40.

7. Tsuji S. General remarks on the populations of Alaska pollock (Theragra chalcogramma (Pallas)) in waters around Hokkaido. J. Hokkaido Fish. Exp. Stn 1978; 35: 1-57.

8. Beverley-Burton M. Population genetics of Anisakis simplex (Nematoda: Ascaridoidea) in Atlantic salmon (Salmo salar) and their use as biological indicators of host stocks. Environ. Biol. Fish. 1978; 3: 369-377.

9. McGladdery SE, Burt MD. Potential of parasites for use as biological indicators of migration, feeding, and spawning behavior of northwestern Atlantic herring (Clupea harengus). Can. J. Fish. Aquat. Sci. 1985; 42: 1957-1968.

10. Nascimento GM. Populations and assemblages of parasites in hake, Merluccius gayi, from the southeastern Pacific Ocean: Stock implications. J. Fish Biol. 1996; 48: 557-568.

11. Boje J, Riget F, Køie M. Helminth parasites as biological tags in population studies of Greenland halibut (Reinhardtius hippoglossoides (Walbaum)), in the north-west Atlantic. ICES J. Mar. Sci., 1997; 54: 886-895. 
12. MacKenzie K, Abaunza P. Parasites as biological tags for stock discrimination of marine fish: A guide to procedures and methods. Fish. Res. 1998; 38: 45-56.

13. Urawa S. Parasites as biological indicators contributing to salmonid biology. Sci. Rep. Hokkaido Salmon Hatchery 1989; 43: $53-74$.

14. Avdeev VV, Avdeev GV. A study of walleye pollock population structure and migration routes using parasitological indicators. In: Proceedings of the International Symposium on the Biology and Management of Walleye Pollock. Alaska Sea Grant Report No. 89-1. 1988; 569-590.

15. Avdeev GV. Infestation by helminths and redistribution of immature walleye pollock Theragra chalcogramma in the Sea of Okhotsk. J. Ichthyol. 1996; 36: 665-673.

16. Kagei N. Euphausiids and their parasites (I). Geiken Tsushin 1979; 328: 53-62.

17. Nagasawa K. The life cycle of Anisakis simplex: A review. In: Ishikura H, Kikuchi K (eds). Intestinal Anisakiasis in Japan: Infected Fish, Sero-Immunological Diagnosis, and Prevention. Springer-Verlag, Tokyo. 1990; 31-40.

18. Køie M, Fagerholm H-P. The life cycle of Contracaecum osculatum (Rudolphi, 1802) sensu stricto (Nematoda, Ascaridoidea, Anisakidae) in view of experimental infections. Parasitol. Res. 1995; 81: 481-489.

19. Hays R, Measures LN, Huot J. Euphausiids as intermediate hosts of Anisakis simplex in the St Lawrence estuary. Can. J. Zool. 1998; 76: 1226-1235.

20. Sasaki M. Survey of parasites of the Alaska pollock, Theragra chalcogramma. J. Hokkaido Fish. Exp. Stn 1973; 30 14-39.

21. Suzuki M, Oishi K. Parasites of Theragra chalcogramma. In: Japanese Society of Fisheries (ed.). Fish and Anisakis. Koseisha Koseikaku, Tokyo. 1974; 113-125.

22. Arthur JR, Margolis L, Whitaker DJ, McDonald TE. A quantitative study of economically important parasites of walleye pollock (Theragra chalcogramma) from British Columbian waters and effects of postmortem handling on their abundance in the musculature. Can. J. Fish. Aquat. Sci. 1982; 39: 710-726.

23. Arthur JR. A survey of the parasites of walleye pollock (Theragra chalcogramma) from the northeastern Pacific Ocean off Canada and a zoogeographical analysis of the parasite fauna of this fish throughout its range. Can. J. Zool. 1984; 62: 675-684.

24. Nagasawa K. Parasites of gadid fishes in Japanese waters (review and bibliography). Sci. Rep. Hokkaido Fish. Exp. Stn 1993; 42: 69-89.

25. Iizuka A, Kurohagi T, Ikuta $\mathrm{K}$, Imai S. Composition of the food of Alaska pollock (Theragra chalcogramma) in Hokkaido with special reference to its local differences. Bull. Hokkaido Reg. Fish. Res. Lab. 1954; 11: 7-20.

26. Yamamura O. Ecological study on demersal fish community off Sendai Bay, northern Japan, with special reference to niche dynamics among dominant fishes. $\mathrm{PhD}$ thesis. Hokkaido University, Hakodate, Japan, 1994.

27. Kooka K, Takatsu T, Kamei Y, Nakatani T, Takahashi T. Vertical distribution and prey of walleye pollock in the northern Japan Sea. Fish. Sci. 1998, 64: 686-693.

28. Suzuki M, Matsufuji R. Survey of parasites from marine fishes. Res. Bull. Nayoro Junior Coll. 1975; 8: 1-30.

29. Nishimura A. Age determination of walleye pollock based on the otoliths (Review). Sci. Rep. Hokkaido Fish. Exp. Stn 1993; 42: 37-49.
30. Koyama T, Kobayashi A, Kumada M, Komiya Y, Oshima T, Kagei N, Machida M. Morphological and taxonomical studies on Anisakidae larvae found in marine fishes and squids. Jpn. J. Parasitol. 1969; 18: 466-487.

31. Shiraki T. Larval nematodes of family Anisakidae (Nematoda) in the northern Sea of Japan, as a causative agent of eosinophilic phlegmone or granuloma in the human gastrointestinal tract. Acta Med. Biol. 1974; 22: 57-98.

32. Bush TO, Lafferty KD, Lotz JM, Shostak AW. Parasitology meets ecology on its own terms: Margolis et al. revisited. I. Parasitol. 1997; 83: 575-583.

33. Kooka K. Effect of feeding environment on the growth pattern of pelagic walleye pollock (Theragra chalcogramma) in the northern Japan Sea. PhD thesis. Hokkaido University, Hakodate, Japan, 1999.

34. Sokal RR, Rohlf JF. Biometry: The Principles and Practice of Statistics in Biological Research, 3rd edn. W.H. Freeman, New York. 1995.

35. Hemmingsen W, Halvorsen O, MacKenzie K. The occurrence of some metazoan parasites of Atlantic cod, Gadus morhua L., in relation to age and sex of the host in Balsfjord $\left(70^{\circ} \mathrm{N}\right)$, North Norway. Polar Biol. 2000; 23: 368-372.

36. Utoh H, Natsume M. Regional difference of age-composition of walleye pollock, Theragra chalcogramma, from the Japan Sea coast of Hokkaido and an interpretation for its cause. Sci. Rep. Hokkaido Fish. Exp. Stn 1993; 42: 215-228.

37. Uspenskaya AV. Parasitic Fauna of Benthic Crustaceans of the Barents Sea. Izdatel'stvo Akademiya Nauk SSSR, Moscow. 1963.

38. Oshima T. A study on the first host of Anisakis. Saishin Igaku 1969; 24: 401-404.

39. Smith JW. Thysanoessa inermis and T. longicaudata (Euphausiidae) as first intermediate hosts of Anisakis sp. (Nematoda: Ascaridata) in the northern North Sea, to the north of Scotland and at Faroe. Nature 1971; 234: 478.

40. Kagei N. Studies on anisakid nematoda (Anisakidae) (IV). Survey of Anisakis larvae in the marine crustacea. Bull. Inst. Publ. Health 1974; 23: 65-71.

41. Oshima T. Anisakis and anisakiasis in Japan and adjacent area. In: Morishita K, Komiya Y, Matsubayashi H (eds). Progress of Medical Parasitology in Japan. Meguro Parasitological Museum, Tokyo. 1972; 304-393.

42. Shimazu T. Some helminth parasites of marine planktonic invertebrates. Bull. Nagano-Ken Junior Coll. 1982; 37: 11-29.

43. Tsuji S. Walleye pollock survey in southwest Okhotsk Sea. Sci. Rep. Hokkaido. Fish. Exp. Stn 1973; 30: 1-22.

44. Ishino K. Stock structure of the southwestern Okhotsk Sea walleye pollock, Theragra chalcogramma, during the feeding migration based on the vertebral number. Sci. Rep. Hokkaido Fish. Exp. Stn 1993; 42: 203-213.

45. Maeda T, Takahashi T, Ueno M. Behaviour in each life period of adult Alaska pollack in the adjacent waters of Funka Bay, Hokkaido. Bull. Jpn. Soc. Sci. Fish. 1983; 49: 577-585.

46. Hamatsu T, Yabuki K. Spawning migration and spawning ground of walleye pollock Theragra chalcogramma distributed along the Pacific coast of eastern Hokkaido. Bull. Hokkaido Natl Fish. Res. Inst. 1995; 59: 31-41.

47. Kagei N. Life history of nematodes of the genus Anisakis. Saishin Igaku 1969; 24: 389-400.

48. Kagei N, Oshima T, Kobayashi A, Kumada M, Koyama T, Komiya Y, Takemura A. Survey of Anisakis spp. (Anisakinae, Nematoda) on marine mammals in the coast of Japan. Jpn. J. Parasitol. 1967; 16: 427-435. 
49. Kuramochi T, Machida M, Araki J, Uchida A, Kishiro T, Nagasawa K. Minke whales (Balaenoptera acutorostrata) are one of the major hosts of Anisakis simplex (Nematoda: Anisakidae) in the northwestern North Pacific Ocean. Rep. Int. Whal. Comm. 1996; 46: 415-419.

50. Miyashita T, Hatanaka H. A note on whaling grounds for the western north Pacific minke whale. Rep. Int. Whal. Comm. 1997; 47: 539-542.

51. Gibson DI, Harris EA, Bray RA, Jepson PD, Kuiken T, Baker JR, Simpson VR. A survey of the helminth parasites of cetaceans stranded on the coast of England and Wales during the period 1990-1994. J. Zool. Soc. Lond. 1998; 244: 563-574.

52. González T, Acuña E. Influence of host size and sex on the endohelminth infracommunities of the red rockfish Sebastes capensis off northern Chile. J. Parasitol. 2000; 86: 854-857.

53. Smith JW. Anisakis simplex (Rudolphi, 1809 det. Krabbe, 1878): Length distribution and variability of L3 of known minimum age from herring Clupea harengus L. J. Helminthol. 1984; 58: 337-340.

54. Hemmingsen W, Lysne DA, Eidnes T, Skorping A. The occurrence of larval ascaridoid nematodes in wild-caught and in caged and artificially fed Atlantic cod, Gadus morhua L., in Norwegian waters. Fish. Res. 1993; 15: 379-386.

55. Brattey J. Effect of temperature on egg hatching in three ascaridoid nematode species from seals. In: Bowen WD (ed.). Population Biology of Sealworm (Pseudoterranova decipiens) in Relation to its Intermediate and Seal Hosts. Can. Bull. Fish. Aquat. Sci. 1990; 222: 27-39.

56. Shimazu T, Oshima T. Some larval nematodes from euphausiid crustaceans. In: Anraku M, Bense K, Kawamura T, Nishizawa S, Parsons TR, Takenouti Y, Tsujita T (eds). Biological Oceanography of the Northern North. Pacific. Idemitsu Shoten, Tokyo. 1972; 403-409.

57. Boily FD, Marcogliese J. Geographical variations in abundance of larval anisakine nematodes in Atlantic cod (Gadus morhua) and American plaice (Hippoglossoides platessoides) from the Gulf of St Lawrence. Can. J. Fish. Aquat. Sci. 1995; 52 (Suppl. 1): 105-115.

58. Nagasawa K. Parasites of pinnipeds (Mammalia: Carnivora) in Japan: Checklist and bibliography. Bull. Nat. Res. Inst. Far Seas Fish. 1999; 36: 27-32.

59. Machida M. Survey on gastric nematodes of the northern fur seal on breeding islands. Jpn. J. Parasitol. 1971; 20: 371-378.

60. Burns JJ. Ribbon seal Phoca fasciata Zimmermann, 1783. In: Ridgway SH, Harrison RJ FRS (eds). Handbook of Marine Mammals, Vol. 2: Seals. Academic Press, London. 1981; 89-109.

61. Shults LM, Frost KJ. Helminth parasites of ribbon seals, Phoca fasciata, in the Bering Sea and their intermediate hosts. Proc. Helminthol. Soc. Wash. 1988; 55: 68-73. 